\title{
ВИКОРИСТАННЯ КЛАСТЕРНОГО АНАЛІЗУ ДЛЯ АВТОМАТИЗАЦІЇ ДІАГНОСТИКИ ПРИ ДИНАМІЧНИХ СЦИНТИГРАФІЧНИХ ДОСЛІДЖЕННЯХ
}

О. В. Дьомін, О. О. Харюк

\author{
Інститут сцинтиляційних матеріалів НАН України \\ Харківський національний університет імені В. Н. Каразіна
}

\section{CLUSTER ANALYSIS AS INSTRUMENT FOR DIAGNOSIS AUTOMATION DURING DYNAMIC SCINTIGRAPHIC STUDIES}

\author{
O. V. Diomin, O. O. Kharyuk \\ Institute for Scintillation Materials of NAS of Ukraine \\ V. N. Karazin Kharkiv National University
}

Вступ. Сьогодні в пілотному режимі працює Грід-система збереження медичних зображень, що накопичує дані пацієнтів. Однак наявність подібних систем, що накопичують і зберігають велику кількість медичних даних, ставить перед науковцями черговий виклик: необхідність обробляти ці дані для статистичних, епідеміологічних, популяційних та інших досліджень. Для проведення такого оброблення в Грід повинен бути повністю автоматизований процес аналізу кожного зображення. На тепер у більшості систем оброблення медичних зображень ручною є перша фаза - виділення зон інтересу, тобто оконтурювання органів і систем. І це робить неможливим Грід оброблення. На нашу думку, для вирішення завдань виділення зон інтересу може бути застосований апарат кластерного аналізу.

Результати та їх обговорення. Нагадаємо, що кластерний аналіз - це спосіб групування багатовимірних об'єктів, заснований на представленні результатів окремих спостережень точками відповідного геометричного простору з подальшим виділенням «згустків» цих точок (кластерів). Опорні пункти кластерного аналізу такі:

- Визначаємо множину об'єктів.

- Кожен об'єкт характеризується поєднанням ознак.

- Множина об'єктів поділяється на кластери, об'єднуючи в один кластер об'єкти 3 подібними ознаками.
- Визначається метрика в просторі ознак (зазвичай Евклідова).

- Мінімізується функціонал, що залежить від розподілу об'єктів по кластерах.

На наш погляд, для застосування апарату кластерного аналізу найбільше підходять динамічні радіонуклідні дослідження. Суть методу радіонуклідної діагностики полягає в тому, що пацієнтові вводиться радіопрепарат, який складається 3 двох частин. Біологічно активна частина включається в фізіологічний процес, що досліджується. Радіоактивна мітка випромінює гамма-кванти, що згодом детектує гамма-камера. Перед введенням (як правило внутрішньовенним) ці два компоненти змішуються й утворюють хімічно стійке з'єднання. Тобто радіонуклідна мітка служить для візуалізації фізіологічного процесу, що проходить в організмі. При проведенні динамічного дослідження гаммакамера записує досить довгу серію кадрів, що представляють послідовні фази фізіологічного процесу в часі, які можна назвати «кіно про процес, що досліджується».

Для цього класу досліджень нами було проведено ізоморфне переведення завдання оброблення медичних зображень на мову кластерного аналізу. Об'єктами є геометричні пікселі зображення. Багатовимірним вектором ознак кожного об'єкта є часова поведінка пікселя, що фіксується камерою в серії кадрів. В якості мінімізації обрано алгоритм кластеризації k-means. 
Алгоритм k-means $є$ алгоритмом неієрархічної кластеризації, а значить має один істотний мінус - необхідно апріорі обирати кількість кластерів. Але, незважаючи на цей недолік, алгоритм k-means належить до одних із найпростіших і найлегших у застосуванні алгоритмів, що має високу швидкість роботи. Використано алгоритм k-means ++. Відмінність k-means ++ від k-means в тому, що в k-means ++ включений алгоритм вибору початкових координат.

Алгоритм k-means ++ застосували для кластеризації функціональних досліджень нирок. У переважній більшості випадків за допомогою розбиття на кластери проведено оконтурювання функціональних органів: нирки, серце, сечовий міхур, тканинне тіло тощо. У тих дослідженнях, де на останніх фазах значно виділяються миска та сечоводи, кластеризація розділяє паренхіму та миску нирки. Ручне виділення зон інтересу проводиться за сумою перших кадрів серії. А оскільки у початковій фазі миска не задіяна, то розділення паренхіми та миски при ручному оконтурюванні нирки є проблемою.

Висновок. Застосування кластерного аналізу для вирішення завдань виділення зон інтересу показало свою ефективність. Воно може бути використане й для вдосконалення програмного забезпечення гамма-камер. 